\title{
Linking biochemical and elemental composition in freshwater and marine crustacean zooplankton
}

\author{
Marc Ventura* \\ National Environmental Research Institute, Vejlsøvej 25, 8600 Silkeborg, Denmark
}

\begin{abstract}
The major groups of biochemical compounds (proteins, lipids, carbohydrates, chitin, nucleic acids and nucleotides) have a distinct functional role and, therefore, incorporation of biochemical interpretations into stoichiometric analysis would improve our current understanding of species life histories and their interactions. A review of the stoichiometric composition of the main biochemical compounds of freshwater and marine zooplankton revealed high constancy. No significant differences were found between marine and freshwater species or between any of the taxonomic groups considered (copepods, cladocerans, euphausiids and mysiids) for most of the main biochemical compounds (triacylglycerol, wax esters, phospholipids and proteins). Therefore, it can be concluded that inter- and intraspecific stoichiometric variability is a result of differences in the proportions of the main biochemical compounds. Comparison of the biochemical composition of 182 freshwater and marine species revealed that freshwater species had lower ATP and free amino acid content and higher RNA content than marine species. The elemental composition of a single copepod species, Calanus finmarchicus, and the averages of each taxonomic group were estimated from the composition of major biochemical compounds and compared with the measured elemental content. Almost all of the measured carbon $(\mathrm{C})$, nitrogen $(\mathrm{N})$ and phosphorus $(\mathrm{P})$ were accounted for. After proteins, nucleic acids were the second most abundant compound in the $\mathrm{N}$ pool of freshwater species, while free amino acids were the second most prevalent compound in marine species. Phospholipids were the most abundant compound in the $\mathrm{P}$ pool of marine species, while in freshwater species nucleic acids were the most abundant compound.
\end{abstract}

KEY WORDS: Elemental composition - Biochemical compounds - Crustacean zooplankton · Freshwater · Marine

Resale or republication not permitted without written consent of the publisher

\section{INTRODUCTION}

The main elemental constituents of freshwater and marine zooplankton have been described extensively in the literature. Their relative content is highly variable, as shown by their percentage ranges on a dry weight basis, which are between 33 and 72 for carbon (C), 6 and 15 for nitrogen (N), 6 and 10 for hydrogen (H) (Båmstedt 1986, Elser et al. 2000a) and 0.6 and 2.5 for phosphorus (P) (Hessen \& Lyche 1991, Mauchline 1998). However, the underlying mechanisms for this wide variation are not yet fully understood. For instance, freshwater cladocerans have a consistently higher $\mathrm{P}$ content than copepods when compared within the same habitat (Andersen \& Hessen 1991, Hessen \& Lyche 1991, Ventura \& Catalan 2005) and, therefore, release compounds with higher N:P ratios (Urabe 1993). Elser \& Hassett (1994) also found that freshwater zooplankton had lower N:P ratios than marine zooplankton, which was attributed to changes in the occurrence of different taxonomic groups in both habitats (Hassett et al. 1997).

Elements do not exist as such in organisms but are combined into biochemical compounds, which have a predominant functional or structural role. Some are used as energy reserves, for example, triacylglycerols and wax esters (Goulden \& Henry 1984, Sargent \& Falk-Petersen 1988). Others, such as ribonucleic acid 
(RNA), are used preferentially during reproductive periods (Main et al. 1997, Saiz et al. 1998, Wagner et al. 1998, Acharya et al. 2004). These 2 types are likely to have oscillations in their body concentrations through the lifetime of an organism. By contrast, compounds with a primarily structural role are more constant during an animal's life (Ventura \& Catalan 2005), examples are proteins, which are related mainly with muscle tissues and directly involved in the animal's movement, phospholipids, which are the main component of cell membranes, deoxyribonucleic acid (DNA), which contains the genetic information of the cell, and chitin, which is a skeletal compound forming the support structures in invertebrates.

Several studies have focused on the description of the general biochemical composition of zooplankton (Mauchline 1998), particularly on the lipid composition in marine zooplankton. However, very few attempts have been made to directly relate the changes in elemental composition with those of the main biochemical compounds (Elser et al. 1996, Sterner \& Elser 2002). An understanding of these relationships would improve the ecological applicability of stoichiometric arguments (Tang \& Dam 1999). For example, within a species, it has been shown that the higher the growth rate, the higher the RNA:DNA ratio, and this applies both to marine species (Saiz et al. 1998, Wagner et al. 1998, Shin et al. 2003) and freshwater species (Main et al. 1997, Elser et al. 2000b, Vrede et al. 2002). Thus, high animal growth rates result in an increase in the $\mathrm{P}$ content of cells due to the relatively high $\mathrm{P}$ content of RNA. These relationships elucidate why the demand for $\mathrm{P}$ is higher in fast-growing species than in species of slow growth (Acharya et al. 2004).

The elemental composition of some biochemical compounds is well known because they are mostly polymers of specific molecules of known composition and structure, such as chitin, nucleic acids, nucleotides and glycogen. Although it is often assumed that the approximate elemental composition of protein and lipid molecules is relatively constant, substantial differences have been found across species. For instance, the amino acid composition in species of 3 freshwater crustacean groups (cladocerans, calanoid copepods and cyclopoid copepods) was found to be speciesspecific (Guisande et al. 2003). Similarly, the fatty acid composition in marine zooplankton varies under different environmental conditions (Sargent \& FalkPetersen 1988). How this variability in the biochemical composition of zooplankton is reflected in their stoichiometry has not yet been approached in detailed studies. Therefore, the aims of this study were to: (1) evaluate the ranges of variability in the relative proportions and stoichiometric composition of main bio- chemical compounds of zooplankton, (2) assess the potential use of an 'average stoichiometric composition' of each main biochemical compound for estimating their relative contribution to the different elemental pools, and (3) investigate which biochemical compounds contribute the most to the elemental composition of zooplankton and look for possible unaccounted sources of elemental compounds.

\section{MATERIALS AND METHODS}

Stoichiometric composition of biochemical compounds. The molecular compositions of the main biochemical compounds (wax esters, triacylglycerols, phospholipids, free amino acids and proteins) were obtained from published studies. Data covered a total of 45 crustacean species belonging to the most common taxonomic groups in both marine and freshwater habitats, such as cladocerans, cyclopoid copepods, calanoid copepods, euphausiids and mysiids (Table 1).

The stoichiometric composition of each biochemical compound was calculated on the basis of its molecular structure. Wax esters are a combination of fatty acids esterified with fatty alcohols, therefore, wax ester mean stoichiometric composition was calculated by averaging the different proportions of the fatty acids and the fatty alcohols separately, and thereafter combining them for each species. Triacylglycerols are 3 molecules of fatty acids combined with a molecule of glycerol, the average fatty acid stoichiometric composition was calculated for each species and then combined with that of glycerol to obtain the average composition for triacylglycerol. The calculation of a mean composition for phospholipids was more complex because phospholipids can be present as different molecules (mainly phosphatidylinositol, phosphatidylserine, phosphatidylcholine, phosphatidylethanolamine, sphingomyelin, lysophosphatidylethanolamine, lysophosphatidylcholine and phosphatidic acid; Strayer 1988) containing a constant molecular composition (non-fatty acid fraction) combined with a variable fatty acid part. Most papers only report the total fatty acid composition of phospholipids. Therefore, information available in the literature on phospholipid fatty acid composition and the relative proportions of different phospholipid molecules across species had to be collected separately. The average fatty acid composition of phospholipids was calculated for each species. The measured proportion of the different phospholipid molecules was obtained for each of the main taxonomic groups (Table 1) and used to calculate the average composition of the non-fatty acid fraction of phospholipids. The average fatty acid composition for each species was then combined with the 
Table 1. Published data on freshwater and marine crustazean zooplankton species used to describe the stoichiometric composition of the main biochemical compounds. Species belonging to the most common crustazean zooplankton groups were selected, such as cladocerans (CL), cyclopoid copepods (CO-CY), calanoid copepods (CO-CA), euphausiids (EU) and mysiids (MY). PL: phospholipid;

TAG: triacylglycerol; AA: amino acids; FA: fatty acids. Total AA = total and protein amino acids

\begin{tabular}{|c|c|c|c|c|c|c|c|c|}
\hline Group & Species & $\begin{array}{c}\text { Total } \\
\text { AA }\end{array}$ & $\begin{array}{c}\text { Free } \\
\text { AA }\end{array}$ & $\begin{array}{l}\text { PL } \\
\text { mole- } \\
\text { cules }\end{array}$ & $\begin{array}{l}\text { PL } \\
\text { FA }\end{array}$ & $\begin{array}{l}\text { TAG } \\
\text { FA }\end{array}$ & $\begin{array}{l}\text { Wax } \\
\text { ester } \\
\text { FA }\end{array}$ & Source \\
\hline \multicolumn{9}{|c|}{ Freshwater } \\
\hline CL & Daphnia cucullata & & & & $\mathrm{x}$ & $\mathrm{x}$ & & Farkas (1979) \\
\hline CL & Daphnia magna & & $\mathrm{x}$ & $\mathrm{x}$ & $\mathrm{x}$ & & & Gardner \& Miller (1981), Farkas et al. (1984) \\
\hline CL & Daphnia pulex & $\mathrm{x}$ & $\mathrm{x}$ & & $\mathrm{x}$ & $\mathrm{x}$ & & Farkas (1979), Dabrowski \& Rusiecki (1983) \\
\hline CL & Daphnia pulicaria & $\mathrm{x}$ & & & & & & Ventura \& Catalan (2005) \\
\hline CL & Ceriodaphnia sp. & $\mathrm{x}$ & $\mathrm{x}$ & & & & & Dabrowski \& Rusiecki (1983) \\
\hline CL & Simocephalus vetulus & & & & $\mathrm{x}$ & $\mathrm{x}$ & & Desvilettes et al. (1994) \\
\hline CL & Eurycercus lamellatus & & & & $\mathrm{x}$ & $\mathrm{x}$ & & Desvilettes et al. (1994) \\
\hline $\mathrm{CO}-\mathrm{CY}$ & Cyclops vicinus & & & $\mathrm{x}$ & $\mathrm{x}$ & $\mathrm{x}$ & & Farkas (1979), Farkas et al. (1984) \\
\hline $\mathrm{CO}-\mathrm{CY}$ & Cyclops strenuus & $\mathrm{x}$ & $\mathrm{x}$ & & & & & Dabrowski \& Rusiecki (1983) \\
\hline $\mathrm{CO}-\mathrm{CY}$ & Cyclops abyssorum & $\mathrm{x}$ & & & & & & Ventura \& Catalan (2005) \\
\hline $\mathrm{CO}-\mathrm{CY}$ & Acanthocyclops vernalis & & & & $\mathrm{x}$ & $\mathrm{x}$ & & Farkas (1979) \\
\hline $\mathrm{CO}-\mathrm{CY}$ & Eucyclops serrulatus & & & & $\mathrm{x}$ & $\mathrm{x}$ & & Desvilettes et al. (1997) \\
\hline $\mathrm{CO}-\mathrm{CA}$ & Epischura baikalensis & & & & $\mathrm{x}$ & $\mathrm{x}$ & & Morris (1984) \\
\hline $\mathrm{CO}-\mathrm{CA}$ & Eudiaptomus gracilis & & & & $\mathrm{x}$ & $\mathrm{x}$ & & Farkas (1979) \\
\hline $\mathrm{CO}-\mathrm{CA}$ & Eudiaptomus zachariasi & $\mathrm{x}$ & $\mathrm{x}$ & & & & & Dabrowski \& Rusiecki (1983) \\
\hline $\mathrm{CO}-\mathrm{CA}$ & Diaptomus sp. & & $\mathrm{x}$ & & & & & Jeffries \& Alzara (1970) \\
\hline $\mathrm{CO}-\mathrm{CA}$ & Diaptomus cyaneus & $\mathrm{x}$ & & & & & & Ventura \& Catalan (2005) \\
\hline \multicolumn{9}{|l|}{ Marine } \\
\hline $\mathrm{CO}-\mathrm{CA}$ & Acartia tonsa & & $\mathrm{x}$ & & & $\mathrm{x}$ & & Jeffries (1969), Ederington et al. (1995) \\
\hline $\mathrm{CO}-\mathrm{CA}$ & Acartia clausi & & $\mathrm{x}$ & & & $\mathrm{x}$ & & Jeffries (1969), Ederington et al. (1995) \\
\hline $\mathrm{CO}-\mathrm{CA}$ & Amallothrix sp. & & & & $\mathrm{x}$ & $\mathrm{x}$ & & Lee et al. (1971a) \\
\hline $\mathrm{CO}-\mathrm{CA}$ & Calanoides acutus & & & & $\mathrm{x}$ & $\mathrm{x}$ & $\mathrm{x}$ & $\begin{array}{l}\text { Reinhardt \& Van Vleet (1986), Albers } \\
\text { et al. (1996), Falk-Petersen et al. (1999) }\end{array}$ \\
\hline $\mathrm{CO}-\mathrm{CA}$ & Calanus finmarchicus & $\mathrm{x}$ & $\mathrm{x}$ & $\mathrm{x}$ & $\mathrm{x}$ & $\mathrm{x}$ & $\mathrm{x}$ & $\begin{array}{l}\text { Cowey \& Corner (1963a), Jeffries \& } \\
\text { Alzara (1970), Sargent \& Falk-Petersen } \\
\text { (1988), Farkas et al. (1988), Albers et al. (1996) }\end{array}$ \\
\hline $\mathrm{CO}-\mathrm{CA}$ & Calanus glacalis & & & & $\mathrm{x}$ & & $\mathrm{x}$ & Albers et al. (1996) \\
\hline $\mathrm{CO}-\mathrm{CA}$ & Calanus helgolandicus & $\mathrm{x}$ & & & $\mathrm{x}$ & $\mathrm{x}$ & $\mathrm{x}$ & Cowey \& Corner (1963b), Lee et al. (1971b) \\
\hline $\mathrm{CO}-\mathrm{CA}$ & Calanus hyperboreus & & & & $\mathrm{x}$ & $\mathrm{x}$ & $\mathrm{x}$ & $\begin{array}{l}\text { Sargent \& Falk-Petersen (1988), } \\
\text { Albers et al. (1996) }\end{array}$ \\
\hline $\mathrm{CO}-\mathrm{CA}$ & Calanus propinquus & & & & $\mathrm{x}$ & $\mathrm{x}$ & & $\begin{array}{l}\text { Albers et al. (1996), Falk-Petersen et al. } \\
\text { (1999) }\end{array}$ \\
\hline $\mathrm{CO}-\mathrm{CA}$ & Calanus simillimus & & & & & $\mathrm{x}$ & & Ward et al. (1996) \\
\hline $\mathrm{CO}-\mathrm{CA}$ & Calanus sp. & & & $\mathrm{x}$ & $\mathrm{x}$ & & & Farkas et al. (1988) \\
\hline $\mathrm{CO}-\mathrm{CA}$ & Pseudocalanus minutus & & $\mathrm{x}$ & & & & & Jeffries \& Alzara (1970) \\
\hline $\mathrm{CO}-\mathrm{CA}$ & Euchaeta antarctica & & & & $\mathrm{x}$ & $\mathrm{x}$ & $\mathrm{x}$ & Hagen et al. (1995), Albers et al. (1996) \\
\hline $\mathrm{CO}-\mathrm{CA}$ & Euchirella rostromagna & & & & $\mathrm{x}$ & $\mathrm{x}$ & $\mathrm{x}$ & Hagen et al. (1995), Albers et al. (1996) \\
\hline $\mathrm{CO}-\mathrm{CA}$ & Gaetanus brevicornis & & & & $\mathrm{x}$ & $\mathrm{x}$ & $\mathrm{x}$ & Lee et al. (1971a) \\
\hline $\mathrm{CO}-\mathrm{CA}$ & Gaussia princeps & & & & $\mathrm{x}$ & $\mathrm{x}$ & $\mathrm{x}$ & Lee et al. (1971a) \\
\hline $\mathrm{CO}-\mathrm{CA}$ & Metridia gerlachei & & & & $\mathrm{x}$ & $\mathrm{x}$ & $\mathrm{x}$ & $\begin{array}{l}\text { Reinhardt \& Van Vleet (1986), Albers } \\
\text { et al. (1996) }\end{array}$ \\
\hline $\mathrm{CO}-\mathrm{CA}$ & Metridia longa & & & & $\mathrm{x}$ & & $\mathrm{x}$ & $\begin{array}{l}\text { Sargent \& Falk-Petersen (1988), Albers } \\
\text { et al. (1996) }\end{array}$ \\
\hline $\mathrm{CO}-\mathrm{CA}$ & Rhincalanus gigas & & & & $\mathrm{x}$ & & & Reinhardt \& Van Vleet (1986) \\
\hline $\mathrm{CO}-\mathrm{CA}$ & Rhincalanus nasutus & & & & $\mathrm{x}$ & $\mathrm{x}$ & $\mathrm{x}$ & Lee et al. (1971a) \\
\hline $\mathrm{CO}-\mathrm{CA}$ & Eurytemora affinis & & $\mathrm{x}$ & & & & & Jeffries \& Alzara (1970) \\
\hline EU & Euphausia crystallorophias & & & & & $\mathrm{x}$ & $\mathrm{x}$ & Falk-Petersen et al. (1999) \\
\hline EU & Euphausia pacifica & $\mathrm{x}$ & $\mathrm{x}$ & & & & & Suyama et al. (1965) \\
\hline EU & Euphausia superba & $\mathrm{x}$ & $\mathrm{x}$ & $\mathrm{x}$ & $\mathrm{x}$ & & & $\begin{array}{l}\text { Suyama et al. (1965), Burkholder et al. } \\
\text { (1967), Sidhu et al. (1970), Srinivasagam } \\
\text { et al. (1971), Ferguson \& Raymont (1974), } \\
\text { Clarke (1980), Mayzaud et al. (2000) }\end{array}$ \\
\hline EU & Euphausia vallentini & $\mathrm{x}$ & & $\mathrm{x}$ & $\mathrm{x}$ & & & $\begin{array}{l}\text { Suyama et al. (1965), Mayzaud } \\
\text { et al. (2003) }\end{array}$ \\
\hline EU & Meganictiphanes norvegica & $\mathrm{x}$ & $\mathrm{x}$ & & & & & Srinivasagam et al. (1971) \\
\hline EU & Thysanoessa macrura & & & $\mathrm{x}$ & $\mathrm{x}$ & & $\mathrm{x}$ & $\begin{array}{l}\text { Kattner et al. (1996), Falk-Petersen } \\
\text { et al. (1999), Mayzaud et al. (2003) }\end{array}$ \\
\hline MY & Neomysis integer & $\mathrm{x}$ & $\mathrm{x}$ & & & & & Srinivasagam et al. (1971) \\
\hline
\end{tabular}


average non-fatty acid fraction obtained for its respective taxonomic group. The total amino acid pool was divided into proteins and free amino acids. The average stoichiometric composition of each fraction and that of the total were calculated for each species. The average of the amino acid stoichiometric composition was obtained after multiplying the stoichiometric composition of each amino acid by their relative proportions in each fraction. Only studies giving complete amino acid composition data were used in order to avoid underestimating sulphur content in stoichiometric calculations. Sulphur-containing amino acids easily degrade and, thus, require special analytical methods that were not always used in the publications surveyed.

Differences in the elemental composition of each main biochemical compound were analysed using the Kruskal-Wallis non-parametric test. Habitat (freshwater or marine) and taxonomic group (cladocerans, cyclopoid and calanoid copepods, euphausiids and mysiids) were the factors included in this analysis.

Estimation of the elemental composition of zooplankton from biochemical compound proportions. To test the potential use of biochemical compound proportions for predicting the average elemental composition of a given species, the biochemical composition of 1 species, the marine copepod Calanus finmarchicus Gunnerus, was used first, followed by the average biochemical composition calculated for each taxonomic group. This 2 stage approach was chosen to avoid in the first stage the potential effect of mixing different species together.

The elemental composition was estimated from the following equation:

$$
W_{i}=\sum_{k=1}^{n} W_{k} M_{k i}
$$

Where $W_{i}$ is the mass fraction of the $i$ elemental component $(\mathrm{C}, \mathrm{H}, \mathrm{N}, \mathrm{O}, \mathrm{P}$ and $\mathrm{S}), W_{k}$ is the mass fraction of the $k$ biochemical compound (protein, triacylglycerol or wax ester, phospholipid, free amino acid, chitin, glycogen, nucleic acid or nucleotide), $M$ is the mass fraction of the $i$ elemental component in the $k$ biochemical compound, and $n$ is the number of biochemical compounds having the $i$ elemental component. All mass fractions are referred to as dry weights in order to facilitate comparison with the measured elemental values in the literature. Thus, the ash content of $C$. finmarchicus or those of each taxonomic group were taken into account in the percentage composition calculation of each compound.

Calanus finmarchicus was chosen for the individual species because of the wealth of data available in the literature on this species. Mayzaud \& Martin (1975), for instance, measured its detailed biochemical and elemental compositions simultaneously. Lipids were assumed to be composed primarily of wax esters and phospholipids, which had been measured separately by those authors, since this species has been shown to use wax esters as its main energy reserve (Sargent \& Falk-Petersen 1988). The nucleic acid proportion was calculated from that of carbohydrates insoluble in tricarboxylic acid (TCA), which were mostly nucleic acid pentoses. The RNA:DNA ratio was assumed to be 5.2 (Wagner et al. 1998). Amongst the main biochemical compounds in zooplankton, only free amino acids and nucleotides had not been measured by the authors. Therefore, for these 2 compounds other values measured for $C$. finmarchicus were obtained from the literature. Thus, free amino acids were assumed to be $4 \%$ (Jeffries \& Alzara 1970) and nucleotides $1.7 \%$ (Balch 1972, Skjoldal \& Båmstedt 1977).

In the second stage, data on average biochemical and elemental composition of freshwater and marine zooplankton were collected from the literature. Some considerations were necessary for some biochemical compounds. For example, total lipid content was collected separately from the relative proportions of the different fractions since the measurement of total lipids was much more frequent than the measurement of the different fractions. It was assumed that the animals were composed of phospholipids, and triacylglycerol or wax esters, or all three. The remaining proportion of lipids, which was usually very small, was allocated to triacylglicerols or wax esters since they are P-free molecules. The values of protein reported in the literature were assumed to be a measure of total amino acid content, and therefore the average protein content shown in this study was the result of the total amino acid pool minus the average proportion of free amino acid for each taxonomic group. The measure of free amino acids was corrected by the extraction efficiency used in each study following the parameters described by Jeffries (1969). In order to facilitate the comparison among the different taxonomic groups, all data used were on the later development stages, predominantly adults. This was especially relevant in the case of nucleic acids where inclusion of ontogenetic variability (unavailable for most of the taxonomic groups) would have prevented between-group comparisons due to relative scarcity of measurements.

To test the differences among the various biochemical and elemental compounds the data were normalised by logarithmic transformation and tested using 1-way ANOVA with 2 factors: taxonomic group (cladocerans, cyclopid copepods, calanoid copepods, euphausiids and mysiids) and habitat (freshwater or marine). The Fisher LSD test was used as post-hoc test. 


\section{RESULTS}

\section{Stoichiometric composition of biochemical compounds}

The analysis of zooplankton species belonging to both freshwater (calanoid and cyclopoid copepods and cladocerans) and marine (calanoid copepods, euphausiids and mysiids) habitats revealed that elemental composition of the main biochemical compounds (wax esters, triacylglycerols, phospholipids, total amino acids, protein amino acids and free amino acids) was very similar (Table 2 ). There were no significant differences in stoichiometric composition across taxonomic groups for any of the biochemical compounds analysed, nor between marine and freshwater species for the 3 lipid compounds or for the protein amino acids. In contrast, the elemental composition of the free amino acids differed between marine and freshwater species (Table 2). The marine species had $5.3 \%$ more $\mathrm{C}(\mathrm{p}=0.002), 4.9 \%$ more $\mathrm{N}(\mathrm{p}=0.01), 8.7 \%$ less oxygen $(p=0.013)$, and $1.2 \%$ less sulphur $(p=0.045)$ than the freshwater species because of their different proportions of amino acids. These differences among freshwater and marine species explain the different total amino acid composition found in organisms from both habitats (Table 2). Due to the lack of significant differences in elemental stoichiometry across taxonomic groups and between marine and freshwater species for all compounds except for free amino acids, an average elemental composition could be calculated for zooplankton lipids and proteins, while 2 different stoichiometric compositions for total and free amino acids were obtained for freshwater and marine species (Table 2).

\section{Average biochemical composition of crustacean zooplankton}

The biochemical compound composition of 182 species belonging to the main crustacean zooplankton groups of freshwater and marine zooplankton was obtained from the literature (Table 3) (see Appendix 1 for a complete list of the species and sources included. Available at www.int-res.com/articles/suppl/m327p233_ app.pdf). In all groups the most abundant compounds were proteins and lipids, the proportions of the former being higher than those of the latter. The most important difference between these 2 main compounds was that protein content ranged between 20 and $70 \%$ of dry weight while lipids exhibited a wider range, from 0.5 to $74 \%$ of dry weight. Free amino acids, chitin and carbohydrates occurred in lower proportions, and their average values ranged between 2 and $10 \%$ of dry weight. Nucleic acids (average RNA ranged from 0.83 to $4.5 \%$ dry weight, average DNA ranged from 0.3 to $3 \%$ dry weight) and especially nucleotides (average ranged from 0.28 to $0.67 \%$ of dry weight) had the lowest proportions.

No significant differences were found among taxonomic groups or between marine and freshwater

Table 2. Stoichiometric composition of the main biochemical compounds of freshwater and marine zooplankton as expressed in percentage mass composition. Mean \pm SD calculated for wax esters, triacylglycerols, phospholipids, proteins and free amino acids in percentage of total mass of each compound. Other main biochemical compounds found in zooplankton that have known molecular compositions are also shown (glycogen, DNA, RNA, chitin and ATP), with the exception of DNA and RNA for which the G-C relationship is assumed to be $40 \%$, as demonstrated for crustacea (Smith 1964). The number of species considered for each compound $(n)$ is indicated

\begin{tabular}{|c|c|c|c|c|c|c|c|}
\hline & $\mathrm{n}$ & $\mathrm{C}(\%)$ & $\mathrm{H}(\%)$ & $\mathrm{O}(\%)$ & $\mathrm{N}(\%)$ & $\mathrm{P}(\%)$ & $\mathrm{S}(\%)$ \\
\hline Wax ester & 14 & $81.0 \pm 0.5$ & $13.0 \pm 0.3$ & $6.0 \pm 0.4$ & 0 & 0 & 0 \\
\hline Triacylglycerol & 22 & $77.3 \pm 0.5$ & $11.5 \pm 0.2$ & $11.2 \pm 0.4$ & 0 & 0 & 0 \\
\hline Phospholipid & 25 & $65.1 \pm 1.1$ & $9.5 \pm 0.2$ & $19.7 \pm 1.2$ & $1.6 \pm 0.1$ & $4.0 \pm 0.2$ & 0 \\
\hline Protein & 15 & $52.8 \pm 0.5$ & $6.9 \pm 0.1$ & $23.2 \pm 0.6$ & $16.0 \pm 0.3$ & 0 & $0.9 \pm 0.2$ \\
\hline Free amino acid & 16 & $42.3 \pm 2.8$ & $7.2 \pm 0.4$ & $27.7 \pm 6.1$ & $18.7 \pm 3.5$ & 0 & $4.1 \pm 1.0$ \\
\hline Total amino acid marine & 6 & $52.8 \pm 0.4$ & $6.9 \pm 0.1$ & $23.2 \pm 0.4$ & $16.1 \pm 0.2$ & 0 & $1.1 \pm 0.2$ \\
\hline Total amino acid freshwater & 6 & $52.0 \pm 0.7$ & $6.9 \pm 0.1$ & $23.1 \pm 0.4$ & $16.6 \pm 0.3$ & 0 & $1.3 \pm 0.3$ \\
\hline Free amino acid marine & 10 & $45.5 \pm 2.9$ & $7.0 \pm 0.4$ & $22.6 \pm 6.4$ & $21.6 \pm 4.0$ & 0 & $3.3 \pm 1.1$ \\
\hline Free amino acid freshwater & 6 & $40.2 \pm 3.1$ & $7.3 \pm 0.4$ & $31.3 \pm 2.6$ & $16.7 \pm 0.9$ & 0 & $4.5 \pm 0.7$ \\
\hline Glycogen & & 44.4 & 6.2 & 49.3 & 0 & 0 & 0 \\
\hline DNA & & 33.7 & 4.0 & 38.6 & 14.8 & 8.9 & 0 \\
\hline RNA & & 31.2 & 3.6 & 42.4 & 14.2 & 8.5 & 0 \\
\hline Chitin & & 45.3 & 6.6 & 41.5 & 6.6 & 0 & 0 \\
\hline ATP & & 23.7 & 3.2 & 41.0 & 13.8 & 18.3 & 0 \\
\hline ADP & & 28.1 & 3.8 & 37.3 & 16.4 & 14.5 & 0 \\
\hline AMP & & 34.4 & 4.6 & 32.1 & 20.1 & 8.9 & 0 \\
\hline
\end{tabular}


Table 3. Biochemical composition of the main taxonomic groups of (a) freshwater and (b) marine zooplankton. All values are given as percentage of dry weight except for the 3 lipid classes, which are expressed as mass percentage of the total lipid content. n: no. of species

\begin{tabular}{|c|c|c|c|c|c|c|c|c|c|}
\hline \multirow[t]{2}{*}{ (a) Freshwater } & \multicolumn{3}{|c|}{ Cladocerans } & \multicolumn{3}{|c|}{ Cyclopoid copepods } & \multicolumn{3}{|c|}{ Calanoid copepods } \\
\hline & Mean \pm SD & Range & $\mathrm{n}$ & Mean $\pm \mathrm{SD}$ & Range & $\mathrm{n}$ & Mean \pm SD & Range & $\mathrm{n}$ \\
\hline ATP & $0.45 \pm 0.04$ & $0.70-0.22$ & 3 & $0.28 \pm 0.03$ & $0.35-0.21$ & 1 & $0.41 \pm 0.08$ & $0.58-0.24$ & 1 \\
\hline \multicolumn{10}{|l|}{ ADP } \\
\hline \multicolumn{10}{|l|}{ AMP } \\
\hline DNA & $0.37 \pm 0.02$ & $0.51-0.20$ & 5 & $3.06 \pm 0.58$ & $3.69-2.56$ & 1 & $2.70 \pm 0.13$ & $2.79-2.60$ & 1 \\
\hline RNA & $4.65 \pm 0.28$ & $6.50-2.00$ & 5 & $3.40 \pm 0.03$ & $3.42-3.38$ & 1 & $3.68 \pm 0.08$ & $3.73-3.62$ & 1 \\
\hline Chitin & $3.21 \pm 1.50$ & $4.94-2.20$ & 3 & $6.83 \pm 4.49$ & $12.00-2.90$ & 2 & $5.40 \pm 1.04$ & $6.60-3.60$ & 1 \\
\hline Carbohydrate & $8.16 \pm 2.75$ & $12.70-4.52$ & 6 & $7.74 \pm 6.31$ & $12.20-1.50$ & 2 & $4.31 \pm 0.86$ & $28.95-0.29$ & 1 \\
\hline Protein & $55.26 \pm 16.78$ & $73.50-20.47$ & 5 & $53.63 \pm 14.5$ & $75.01-25.61$ & 3 & $48.24 \pm 16.27$ & $75.01-25.61$ & 3 \\
\hline Free amino acids & $2.99 \pm 2.72$ & $6.92-0.60$ & 4 & $2.04 \pm 0.56$ & $2.94-1.09$ & 3 & $2.04 \pm 0.56$ & $2.94-1.09$ & 3 \\
\hline Total lipids & $18.87 \pm 12.72$ & $66.50-1.61$ & 12 & $28.06 \pm 20.39$ & $73.60-6.00$ & 3 & $39.34 \pm 14.66$ & $70.00-1.90$ & 9 \\
\hline Phospholipids & $38.60 \pm 15.49$ & $49.55-27.65$ & 2 & & & & $13.78 \pm 11.67$ & $27.00-4.90$ & 3 \\
\hline Triacylglycerol & $61.40 \pm 15.49$ & $72.35-50.45$ & 2 & & & & $86.22 \pm 11.67$ & $95.10-73.00$ & 3 \\
\hline Wax esters & & & & & & & & & \\
\hline \multirow[t]{2}{*}{ (b) Marine } & \multicolumn{3}{|c|}{ Mysiids } & \multicolumn{3}{|c|}{ Euphausiids } & \multicolumn{3}{|c|}{ Calanoid copepods } \\
\hline & Mean \pm SD & Range & $\mathrm{n}$ & Mean \pm SD & Range & $\mathrm{n}$ & Mean \pm SD & Range & $\mathrm{n}$ \\
\hline ATP & $0.62 \pm 0.17$ & $0.69-0.35$ & 2 & $0.37 \pm 0.29$ & $0.85-0.08$ & 1 & $0.67 \pm 0.02$ & $1.70-0.39$ & 13 \\
\hline ADP & $0.33 \pm 0.11$ & $0.73-0.03$ & 2 & $0.73 \pm 0.31$ & $1.34-0.11$ & 1 & $0.27 \pm 0.07$ & $1.47-0.00$ & 9 \\
\hline AMP & $0.19 \pm 0.10$ & $0.60-0.00$ & 2 & $0.09 \pm 0.50$ & $1.10-0.00$ & 1 & $0.16 \pm 0.04$ & $0.71-0.00$ & 9 \\
\hline DNA & & & & $0.33 \pm 0.59$ & $1.60-0.07$ & 1 & $0.67 \pm 1.09$ & $3.92-0.06$ & 5 \\
\hline RNA & & & & $0.53 \pm 0.57$ & $2.13-0.18$ & 1 & $2.14 \pm 0.57$ & $6.80-0.31$ & 7 \\
\hline Chitin & $7.10 \pm 0.65$ & $8.40-5.80$ & 1 & $4.83 \pm 3.82$ & $10.66-2.30$ & 1 & $4.94 \pm 2.12$ & $9.30-2.10$ & 13 \\
\hline Carbohydrate & $3.20 \pm 1.14$ & $5.40-2.40$ & 1 & $2.18 \pm 0.09$ & $2.36-2.01$ & 1 & $2.82 \pm 2.04$ & $8.50-0.20$ & 19 \\
\hline Protein & $37.41 \pm 20.64$ & $66.66-39.14$ & 3 & $43.90 \pm 7.69$ & $69.21-30.00$ & 15 & $38.74 \pm 11.20$ & $64.34-23.94$ & 37 \\
\hline Free amino acids & $9.68 \pm 1.90$ & $13.60-5.94$ & 3 & $5.26 \pm 4.04$ & $10.70-2.00$ & 2 & $10.89 \pm 4.08$ & $19.35-5.06$ & 5 \\
\hline Total lipids & $13.67 \pm 3.82$ & $24.00-8.20$ & 3 & $12.09 \pm 9.26$ & $59.70-0.43$ & 20 & $25.08 \pm 15.72$ & $73.00-1.90$ & 93 \\
\hline Phospholipids & $41.56 \pm 15.82$ & $51.00-23.30$ & 2 & $59.89 \pm 17.76$ & $84.68-35.18$ & 8 & $41.54 \pm 24.92$ & $84.55-1.00$ & 74 \\
\hline Triacylglycerol & $39.04 \pm 23.85$ & $56.29-11.82$ & 3 & $29.79 \pm 12.00$ & $51.03-15.32$ & 8 & $18.31 \pm 17.23$ & $76.50-0.00$ & 74 \\
\hline Wax esters & $19.41 \pm 18.92$ & $37.81-0.00$ & 3 & $10.32 \pm 15.97$ & $40.77-0.00$ & 8 & $40.15 \pm 32.51$ & $94.13-0.00$ & 74 \\
\hline
\end{tabular}

species for proteins, carbohydrates and chitin (only differences between freshwater and marine species could be tested for chitin) due to the high variability of most compounds in each taxonomic group (shown by standard deviations and maximum-minimum ranges in Table 3 and ANOVA tests in Table 4). In contrast, there were differences in the content of adenosine triphosphate (ATP), free amino acids and RNA between marine and freshwater species. Freshwater species had a lower ATP content than marine species (average for freshwater species ranged from 0.28 to $0.45 \%$ dry weight and for marine species ranged from 0.37 to $0.67 \%$ dry weight). In contrast, freshwater species had higher RNA content compared with marine species (average freshwater RNA ranged from 2.8 to $4.5 \%$ dry weight and average marine RNA was $0.8 \%$ dry weight for euphausiids and $2.1 \%$ dry weight for calanoid copepods). The free amino acid content was much higher in marine species than in freshwater species (average in freshwater species ranged between 2 to $3 \%$ dry weight whereas average in marine species ranged from 5.3 to $10.9 \%$ dry weight). The DNA con- tent of freshwater cyclopoid and calanoid copepods was only measured for 1 species from the former group and 2 from the latter. These 3 species had a much higher DNA content than the other 3 groups (3 and $2 \%$ of dry weight for freshwater cyclopoid and calanoid copepods, respectively, versus $0.7,0.6$ and $0.3 \%$ dry weight for marine calanoid copepods, euphausiids and freshwater cladocerans, respectively).

Total lipids were the only compound showing significant differences for both taxon and habitat in the ANOVA test due to the higher lipid content of freshwater calanoid copepods than that of marine calanoid copepods, euphausiids, mysiids as well as freshwater cladocerans, and due to the higher lipid content of freshwater cladocerans and cyclopid copepods than that of euphausiids (Table 4 , post-hoc test, $\mathrm{p}<0.05$ ). Within lipid classes, wax esters were present only in the 3 marine groups and were significantly higher in marine calanoid copepods than in euphausiids (Table 4, post-hoc test, $\mathrm{p}<0.05$ ). Triacylglycerols were the dominant lipid class in freshwater cladocerans and calanoid copepods (no data on lipid class composition 
Table 4. ANOVA table for variability among taxonomic groups (cladocerans, cyclopoid copepods, calanoid copepods, euphausiids and mysiids) and habitats (marine vs. freshwater) in the composition of the main biochemical compounds of crustacean zooplankton. A summary and description of the units of each compound are given in Table 3

\begin{tabular}{|c|c|c|c|c|}
\hline Variable & $\mathrm{df}$ & MS & $F$ & $\mathrm{p}$ \\
\hline \multicolumn{5}{|l|}{ Protein } \\
\hline Taxon & 4 & 0.008 & 0.752 & 0.561 \\
\hline Habitat & 1 & 0.000 & 0.001 & 0.970 \\
\hline Residuals & 62 & 0.010 & & \\
\hline \multicolumn{5}{|c|}{ Free amino acid } \\
\hline Taxon & 4 & 0.051 & 0.821 & 0.536 \\
\hline Habitat & 1 & 1.136 & 18.206 & 0.001 \\
\hline Residuals & 12 & 0.062 & & \\
\hline \multicolumn{5}{|l|}{ Total lipid } \\
\hline Taxon & 4 & 0.608 & 7.088 & 0.000 \\
\hline Habitat & 1 & 0.580 & 6.762 & 0.010 \\
\hline Residuals & 135 & 0.086 & & \\
\hline \multicolumn{5}{|l|}{ Phospholipid } \\
\hline Taxon & 3 & 0.053 & 0.715 & 0.546 \\
\hline Habitat & 1 & 0.177 & 2.402 & 0.125 \\
\hline Residuals & 85 & 0.073 & & \\
\hline \multicolumn{5}{|c|}{ Triacylglycerol } \\
\hline Taxon & 3 & 0.332 & 1.166 & 0.328 \\
\hline Habitat & 1 & 3.590 & 12.597 & 0.001 \\
\hline Residuals & 85 & 0.285 & & \\
\hline \multicolumn{5}{|l|}{ Wax ester } \\
\hline Taxon & 2 & 7.010 & 4.497 & 0.014 \\
\hline Residuals & 82 & 1.559 & & \\
\hline \multicolumn{5}{|c|}{ Carbohydrate } \\
\hline Taxon & 4 & 0.129 & 1.092 & 0.380 \\
\hline Habitat & 1 & 0.069 & 0.587 & 0.450 \\
\hline Residuals & 28 & 0.118 & & \\
\hline \multicolumn{5}{|l|}{ Chitin } \\
\hline Habitat & 1 & 0.013 & 0.220 & 0.644 \\
\hline Residuals & 21 & 0.059 & & \\
\hline \multicolumn{5}{|l|}{ DNA } \\
\hline Habitat & 1 & 0.112 & 0.395 & 0.542 \\
\hline Residuals & 12 & 0.285 & & \\
\hline \multicolumn{5}{|l|}{ RNA } \\
\hline Habitat & 1 & 0.632 & 8.754 & 0.010 \\
\hline Residuals & 14 & 0.072 & & \\
\hline \multicolumn{5}{|l|}{ ATP } \\
\hline Habitat & 1 & 0.120 & 4.652 & 0.044 \\
\hline Residuals & 19 & 0.026 & & \\
\hline
\end{tabular}

were found for cyclopoid copepods) and were also present in marine species. Freshwater species had a significantly higher average concentration of triacylglycerol compared with marine species due to the predominance of wax esters in marine species (Table 4). However, no significant differences were found between the different taxonomic groups in their triacylglycerol content, which varied widely within each group. For most taxonomic groups phospholipids were the class showing the lowest average proportion among the 3 dominant lipid groups, with the exception of phospholipids in euphausiids that, on average, constituted $60 \%$ of the total lipids.

\section{Average elemental composition of crustacean zooplankton}

In order to compare the elemental composition estimated from biochemical compounds with that of zooplankton measured directly, data from literature sources for the same taxonomic groups considered for the biochemical information were collected for 115 species (see Appendix 1 for a complete list of the species and sources included). Similar to the biochemical compounds, the 4 elements showed high within-group variability for $\mathrm{C}, \mathrm{N}, \mathrm{H}$ and $\mathrm{P}$ (as shown by $\mathrm{SD}$ values and ranges in Table 5). Significant differences existed among taxonomic groups in their $\mathrm{C}$ content (Table 6) due to the higher $\mathrm{C}$ content in freshwater calanoid copepods compared with that in freshwater cladocerans, euphausiids and mysiids (post-hoc test, $\mathrm{p}<0.05$ ). No habitat-induced differences were seen. In contrast, no differences occurred in the $\mathrm{N}$ and $\mathrm{H}$ content between the 6 taxonomic groups. Phosphorus was the element exhibiting the highest among-group variability in the ANOVA test where it was significant at both taxon and habitat level (Table 6). These differences can be ascribed to the fact that the average content of $\mathrm{P}$ was lower for freshwater calanoid copepods than for marine calanoid copepods and freshwater cladocerans (post-hoc test, p < 0.05). Freshwater cladocerans also had a higher average $\mathrm{P}$ content than cyclopoid copepods (post-hoc test, p < 0.05).

\section{Estimation of zooplankton elemental composition from biochemical compounds}

The comparison of the directly measured elemental composition with that estimated from the proportions of main biochemical compounds in Calanus finmarchicus showed close agreement for the 3 key elements (C, N and P), the latter accounting for 90.5, 86.4 and $89 \%$, respectively, of the total body $\mathrm{C}, \mathrm{N}$ and $\mathrm{P}$ content (Fig. 1A). The relative contribution of each biochemical compound to the pool of each element was also calculated (Fig. 1B). Proteins and lipids accounted for $80 \%$ of the total $\mathrm{C}$ and $\mathrm{H}$ content, whereas most of the $\mathrm{N}$ was due to proteins and free amino acids (67.4 and $6.9 \%$, respectively). Regarding the $\mathrm{P}$ pool, nucleic acids accounted for $41.8 \%$, phospholipids accounted for $10.7 \%$ and nucleotides for $36.5 \%$ of the total P.

Since most of the elemental composition of Calanus finmarchicus was accounted for the biochemical compounds, the same approach was applied to the average biochemical composition found for each of the different zooplankton groups (Table 3). The average biochemical composition for each compound was then multiplied by their respective stoichiometric com- 
Table 5. Elemental composition of the main taxonomic groups of (a) freshwater and (b) marine zooplankton. Values are \% dry weight. $\mathrm{N}$ : no. of species

\begin{tabular}{|c|c|c|c|c|c|c|c|c|c|}
\hline \multirow[t]{2}{*}{ (a) Freshwater } & \multicolumn{3}{|c|}{ Cladocerans } & \multicolumn{3}{|c|}{ Cyclopoid copepods } & \multicolumn{3}{|c|}{ Calanoid copepods } \\
\hline & Mean $\pm \mathrm{SD}$ & Range & $\mathrm{n}$ & Mean \pm SD & Range & $\mathrm{n}$ & Mean \pm SD & Range & $\mathrm{n}$ \\
\hline Ash & $11.79 \pm 7.91$ & $30.30-2.50$ & 5 & $4.97 \pm 0.44$ & $10.43-2.40$ & 2 & $4.34 \pm 1.20$ & $5.50-2.90$ & 4 \\
\hline Carbon & $48.00 \pm 8.29$ & $75.25-33.42$ & 21 & $49.65 \pm 4.41$ & $58.80-44.23$ & 5 & $55.59 \pm 4.54$ & $62.10-49.80$ & 5 \\
\hline Nitrogen & $9.4 \pm 1.70$ & $14.56-6.40$ & 29 & $11.24 \pm 2.06$ & $15.12-9.72$ & 7 & $9.23 \pm 2.05$ & $11.30-5.80$ & 11 \\
\hline Hydrogen & $7.5 \pm 0.47$ & $10.01-6.12$ & 8 & $7.60 \pm 0.42$ & $7.89-7.30$ & 2 & $7.80 \pm 0.00$ & $7.80-7.80$ & 2 \\
\hline Phosphorus & $1.30 \pm 0.42$ & $2.49-0.62$ & 25 & $1.11 \pm 0.58$ & $1.92-0.46$ & 5 & $0.69 \pm 0.23$ & $1.10-0.50$ & 9 \\
\hline \multirow[t]{2}{*}{ (b) Marine } & \multicolumn{3}{|c|}{ Mysiids } & \multicolumn{3}{|c|}{ Euphausiids } & \multicolumn{3}{|c|}{ Calanoid copepods } \\
\hline & Mean \pm SD & Range & $\mathrm{n}$ & Mean \pm SD & Range & $\mathrm{n}$ & Mean \pm SD & Range & $\mathrm{n}$ \\
\hline Ash & $14.08 \pm 6.50$ & $22.50-7.90$ & 4 & $12.55 \pm 2.67$ & $15.80-8.10$ & 14 & $6.60 \pm 3.91$ & $19.80-2.10$ & 31 \\
\hline Carbon & $41.90 \pm 0.71$ & $42.40-41.40$ & 2 & $44.58 \pm 3.82$ & $54.00-34.80$ & 4 & $50.70 \pm 7.14$ & $67.51-25.90$ & 29 \\
\hline Nitrogen & $10.15 \pm 2.53$ & $12.15-7.30$ & 3 & $10.20 \pm 0.43$ & $12.10-7.64$ & 4 & $9.54 \pm 2.46$ & $14.88-4.40$ & 30 \\
\hline Hydrogen & $6.75 \pm 0.07$ & $6.80-6.70$ & 2 & $7.34 \pm 0.36$ & $7.70-6.40$ & 4 & $7.76 \pm 1.40$ & $10.30-4.40$ & 20 \\
\hline Phosphorus & 1.10 & & 1 & $0.85 \pm 0.07$ & $1.20-0.80$ & 2 & $1.06 \pm 0.41$ & $2.02-0.43$ & 10 \\
\hline
\end{tabular}

position (Table 2) in order to estimate the elemental composition of each taxonomic group (Fig. 2). Since literature data were not available on the ADP and adenosine monophosphate (AMP) content of the 3 freshwater groups, in this study the ATP concentration found for each group and the ratio of these 2 compounds to ATP of marine calanoid copepods was used to estimate ADP and AMP concentrations. Also, as literature data on lipid class composition of freshwater cyclopoid copepods were unavailable, the same proportions of phospholipids and triacylglycerols reported for freshwater calanoid copepods were used.

Table 6. ANOVA table for the variability among taxonomic groups (cladocerans, cyclopoid copepods, calanoid copepods, euphausiids and mysiids) and habitats (marine vs. freshwater) in the composition of the main elemental compounds of crustacean zooplankton. A summary and description of the units of each compound are given in Table 3

\begin{tabular}{|lcccc|}
\hline Variable & df & MS & $F$ & $\mathrm{p}$ \\
\hline Carbon & & & & \\
Taxon & 4 & 0.010 & 2.605 & 0.045 \\
Habitat & 1 & 0.008 & 2.133 & 0.149 \\
Residuals & 60 & 0.004 & & \\
Hydrogen & & & & \\
Taxon & 4 & 0.002 & 0.400 & 0.807 \\
Habitat & 1 & 0.000 & 0.039 & 0.845 \\
Residuals & 32 & 0.004 & & \\
Nitrogen & & & & \\
Taxon & 4 & 0.014 & 1.492 & 0.213 \\
Habitat & 1 & 0.001 & 0.099 & 0.754 \\
Residuals & 78 & 0.010 & & \\
Phosphorus & & & & \\
Taxon & 4 & 0.112 & 4.619 & 0.003 \\
Habitat & 1 & 0.141 & 5.815 & 0.020 \\
Residuals & 46 & 0.024 & & \\
\hline
\end{tabular}

A comparison between the average measured elemental composition of each element and zooplankton group and that estimated from the biochemical compounds showed very similar values (Fig. 2). Carbon was the element with the best correspondence between measured and estimated values, the average and standard deviation of the estimated value being $103.1 \pm 2.4 \%$ of the measured composition for all groups. Also, estimated $\mathrm{N}$ and $\mathrm{H}$ values showed strong agreement with measured values, estimated $\mathrm{N}$ and $\mathrm{H}$ contents were $97.2 \pm 7.8$ and $94.4 \pm 6.7 \%$ of the measured contents, respectively. The taxonomic groups with the highest deviations in $\mathrm{H}$ values were freshwater cladocerans and euphausiids (88.0 and $85.7 \%$ of the measured values, respectively), and in $\mathrm{N}$ value was cyclopoid copepods (85.0\% of the measured value). Phosphorus was the element exhibiting the highest deviations between the estimated and measured elemental content due to the $\mathrm{P}$ content in freshwater cladocerans and mysiids, the estimated P being 60.9 and $50.1 \%$, respectively, which is indicative of an important disagreement between the measured and the estimated values.

For all taxonomic groups, the relative contribution of each biochemical compound (Fig. 3) showed that protein was generally the compound contributing the most to the $\mathrm{C}$ and $\mathrm{H}$ pools followed by lipids, with the exception of freshwater and marine calanoid copepods, which exhibited almost similar lipid and protein contributions. In the 3 freshwater groups, carbohydrates and chitin were the next most abundant compounds (the average of each taxonomic group ranged from 2.9 to $7.1 \%$ of the $\mathrm{C}$ or $\mathrm{H}$ pool), while in the 3 marine groups free amino acids were most abundant after protein and lipids (ranging from 5.6 to $12.6 \%$ of the $\mathrm{C}$ or $\mathrm{H}$ pool). The other biochemical compounds had a minor importance in the pool of these 2 com- 

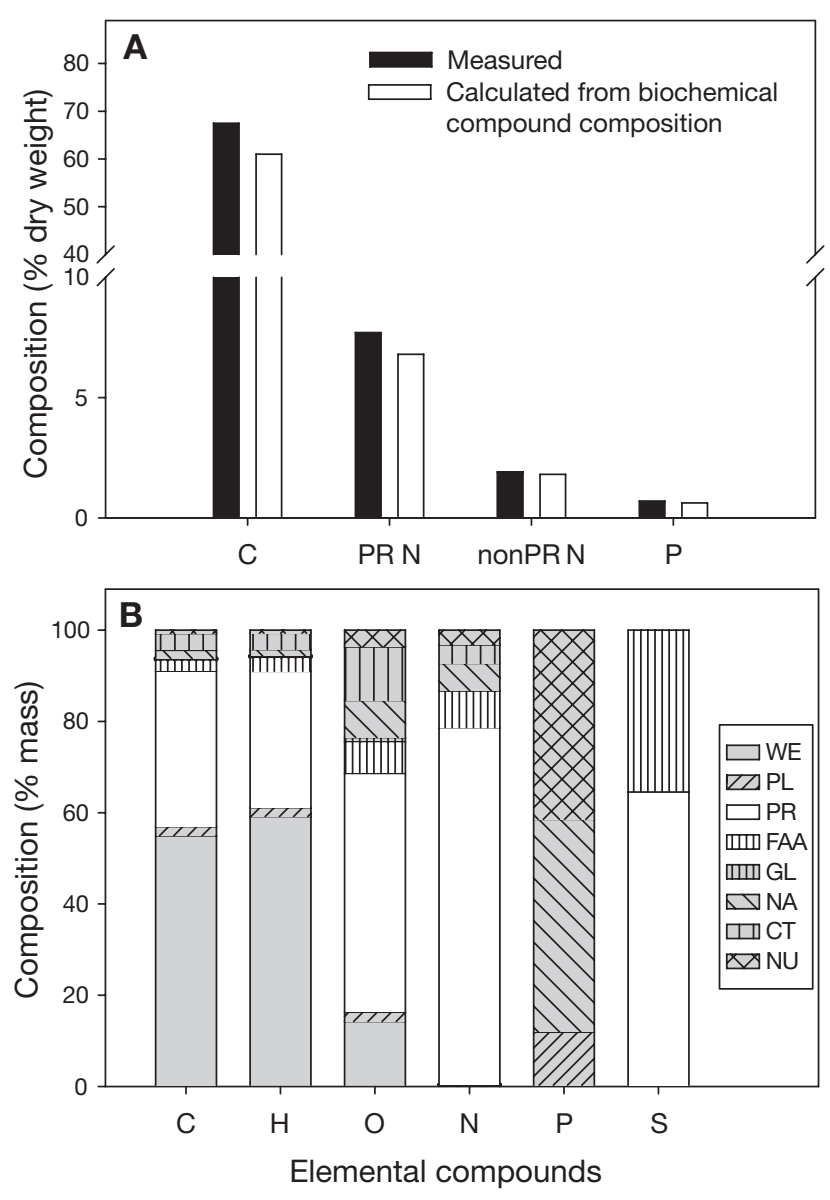

Fig. 1. Biochemical fractionation of the elemental compound composition in Calanus finmarchicus. (A) Measured versus calculated elemental composition. The calculated elemental composition was obtained using main biochemical compound compositions and their stoichiometric composition (Table 2, see text for details). C: carbon; PR N: protein nitrogen; nonPR N: non-protein nitrogen; P: phosphorus. Measured elemental and biochemical compound data are mostly from Mayzaud \& Martin (1975). (B) Major biochemical compounds' contribution to each element. WE: wax ester; PL: phospholipid; PR: protein; FAA: free amino acids; GL: glycogen; NA: nucleic acids; CT: chitin; NU: nucleotides

pounds. The $\mathrm{N}$ pool was dominated mainly by proteins (accounting from 68 to $84 \%$ of the average $\mathrm{N}$ content). Nucleic acids were more abundant in the freshwater groups than in the marine groups $(6.4-9.6 \%$ and $2.3-4.5 \%$ for freshwater and marine groups, respectively). In comparison, free amino acids made up an important proportion of the $\mathrm{N}$ content of marine groups (ranging from 10 to $20.4 \%$ of the pool). Phospholipids accounted for $47-53 \%$ of the P pool in the averages of the marine groups, the corresponding values for freshwater groups being 25-39\%. For the freshwater taxonomic groups nucleic acids accounted for $49-63 \%$ of the $\mathrm{P}$ content, the corresponding values being $14-29 \%$
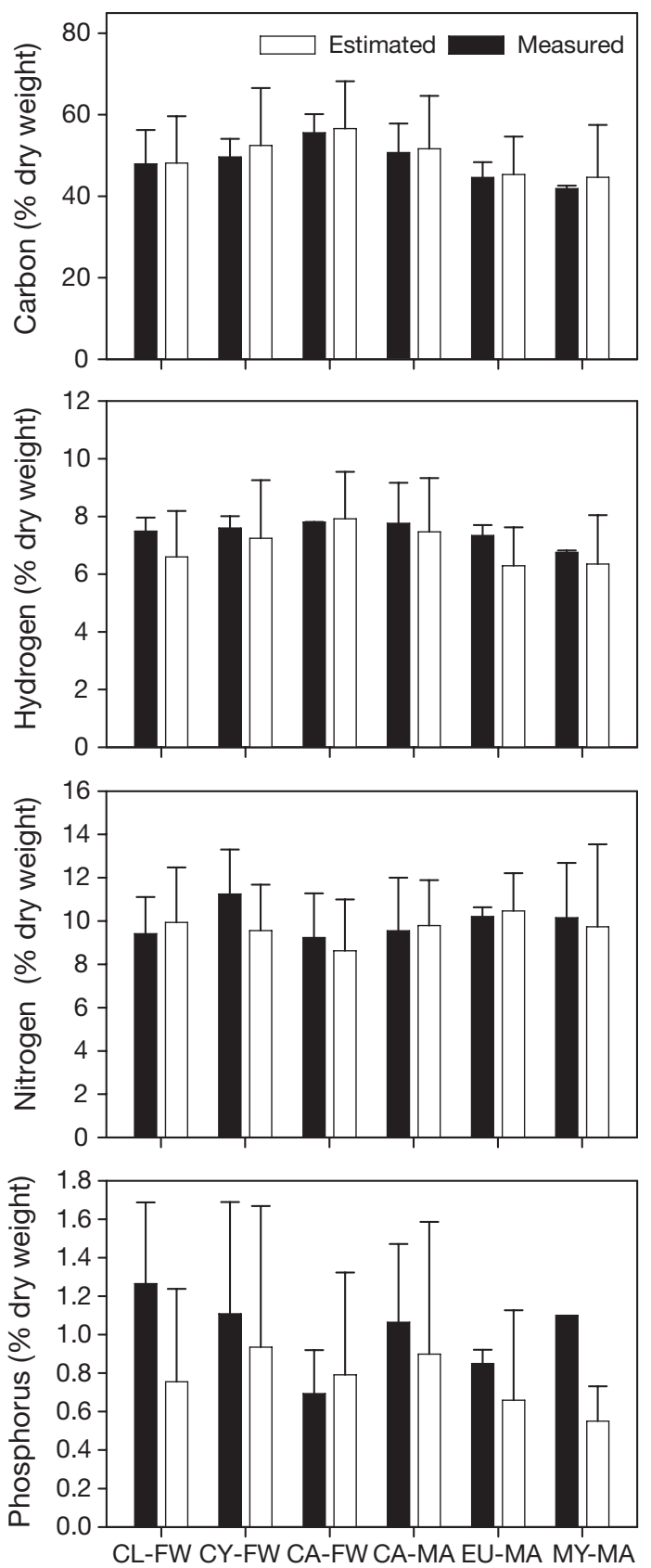

Fig. 2. Comparison between the average measured elemental composition of the main freshwater and marine zooplankton groups (Table 5) and that estimated from their average biochemical composition (Table 3) as well as the stoichiometric composition of each biochemical compound (Table 2). The estimated elemental composition was first transformed from ash-free dry weight to dry weight with the average ash content determined for each taxonomic group (Table 5). See text for detailed calculation procedure. Error bars represent SD of the mean. For the estimated elemental composition SD are those propagated from the variability in the measurement of the biochemical compounds. CL-FW: freshwater cladocerans; CY-FW: freshwater cyclopoid copepods; CA-FW: freshwater calanoid copepods; CA-MA: marine calanoid copepods; EU-MA: marine euphausiids; MY-MA: marine mysiids 


\begin{tabular}{|ll|}
\hline$\square$ Wax ester & $\square$ Glycogen \\
$\square \triangle$ Triacylglycerol & $\square$ Chitin \\
$\square$ Phospholipid & $\square$ RNA \\
$\square$ Free amino acid & $\square$ DNA \\
$\square$ Protein & Nucleotides \\
\hline
\end{tabular}
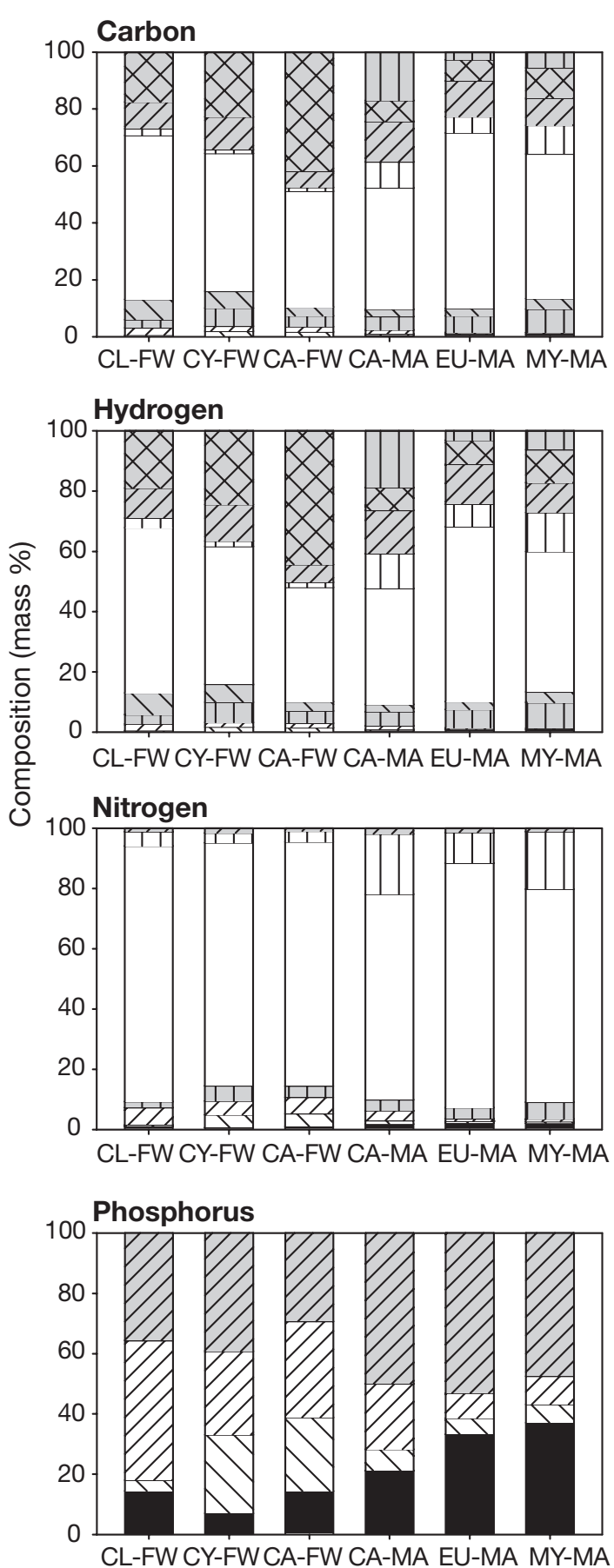

Fig. 3. Relative contribution of each biochemical compound to the average elemental composition of each of the main elements (excluding oxygen) of the main taxonomic groups of crustacean zooplankton. Mass fractions were calculated as percentage of dry weight. Taxonomic group abbreviations are the same as in Fig. 2 for the marine species. In contrast, nucleotides constituted $21-37 \%$ of the P pool in marine groups, but were much less important in the 3 freshwater groups (7-14\% of the $\mathrm{P}$ pool).

\section{DISCUSSION}

\section{Biochemical differences between freshwater and marine species}

Among the different biochemical compounds, protein, phospholipids, carbohydrates and chitin showed no significant differences either between taxonomic groups or habitat types (freshwater versus marine). In contrast, differences were found between marine and freshwater species and among some taxonomic groups for lipids, free amino acids, nucleotides and nucleic acids. Among these latter compounds, lipids are those which have received the highest research effort (140 species were found with data on lipid content, which was more than twice the number of species for which data on protein were found; Table 3). Lipids also exhibited the highest variability in minimum-maximum ranges, most significantly so for copepods. Triacylglycerols and wax esters were the lipid classes distinguishing freshwater from marine species, triacylglycerols being the main energy storage compound in freshwater species (e.g. Farkas 1979, Goulden \& Place 1993). Investigations have shown 2 species of freshwater calanoid copepods (Limnocalanus macrurus and Senecella calanoides, Cavaletto et al. 1989) to use wax esters. However, as these have a much localised distribution and are not representative of the majority of freshwater calanoid copepods in terms of lipid storage mode (Cavaletto et al. 1989), they were not included in this study's lipid class calculations. In contrast, both triacylglycerols and wax esters have been found in marine species (e.g. reviewed by Båmstedt 1986, Mauchline 1998). The intra-specific and inter-specific variability in lipid content, and thus in the relative allocation to energy reserves, has been shown to depend on the life histories of the different species, species accumulating lipids during winter for later use in reproduction showing the highest intra-specific variability, both in freshwater (Vanderploeg et al. 1992, Ventura \& Catalan 2005) and especially in marine Arctic and Antarctic species (Mauchline 1998).

The other compounds shown in this study to differ between freshwater and marine species (free amino acids, nucleic acids and nucleotides, in terms of number of species found for each compound) have been subject to less intensive research efforts despite the fact they are important compounds in both the $\mathrm{N}$ and $\mathrm{P}$ pools. Crustacean zooplankton, like other aquatic 
invertebrates, use free amino acids as the main regulatory compounds for intracellular osmolarity in muscle tissue (Hochachka \& Somero 2002). The higher free amino acid concentration of marine zooplankton as well as the different amino acid composition have been shown to be related with environmental salinity (Harris 1969, Jeffries \& Alzara 1970). Therefore, the difference in the relative proportion of amono acids between freshwater and marine habitats is due to different physiological adaptation.

ATP has been used as an estimator of zooplanktonic biomass (Skjoldal \& Båmstedt 1977, Skjoldal 1981) due to its constant relationship with $\mathrm{C}$, even after zooplankton have starved for several days (Balch 1972). However, it has also been shown that the quantification of ATP is very sensitive to the extraction method used. Dimethylsulfoxide extraction, the method used for analysing the freshwater species, is more efficient than using TRIS-buffer, the method used for the marine species (Amyot et al. 1992). Since ATP concentrations in freshwater species in this study were lower than those in marine species, it is unlikely that differences in extraction efficiency are the cause of the values found. In contrast, it is possible that that these differences might be even greater if the same extraction method would have been used in the species of both habitats.

RNA is an essential component of protein synthesis and its concentration is higher in organisms with faster growth rates, both within the ontogenetic development of a single species and among different species (Main et al. 1997, Saiz et al. 1998, Wagner et al. 1998, Elser et al. 2003, Acharya et al. 2004). The higher RNA content of freshwater species compared with marine species found in this study was, however, not related to different development stages, since only data on adults were used. The result seems to support current findings that marine species have relatively longer life cycles than freshwater species (Mauchline 1998, Santer 1998) and, therefore, expectedly lower growth rates. In contrast to RNA, DNA serves to store genetic information, which is more constant within an organism's ontogenetic development (Wagner et al. 1998, Shin et al. 2003). Moreover, through its influence on cell size and cell division rates, the nuclear DNA content has been shown to be related with developmental rate and body size in both marine calanoid copepods (McLaren et al. 1966, 1989) and freshwater cyclopoid copepods (Wyngaard \& Rasch 2000, Wyngaard et al. 2005). Contrasting with other animal groups (Gregory 2001), there is a wide variability in the genome size of copepods (McLaren et al. 1966, McLaren et al. 1989, Wyngaard \& Rasch 2000, Wyngaard et al. 2005), which has been explained by the ability of some copepods to reduce the size of their somatic nuclear genomes by 35-99\% during embryonic chromatin diminution (Wyngaard \& Rasch 2000). The DNA content of the 3 species of freshwater cyclopoid and calanoid copepods reported in this study (Table 3) lies within the variability found in marine calanoid copepods (from 0.06 to $3.92 \%$ of dry weight). Therefore, the difference between the 2 freshwater copepod groups and the marine group is probably not related to their different habitat, but is a result of the individual characteristics of the different species. In contrast to copepods, cladocerans had a lower and more constant DNA content, which is probably due to their 'miniature' genome size (Beaton \& Hebert 1989, Dufresne \& Hebert 1995).

\section{Disagreement between measured and estimated elemental composition}

The elemental composition estimated from the biochemical compounds agreed well with those directly measured for Calanus finmarchicus and the average values of the taxonomic groups. The agreement was particularly pronounced for the taxonomic averages considering the fact that the averages obtained for the biochemical compounds and elements did not necessarily include the same species (Appendix 1). The slight discrepancies found between direct and estimated elemental proportions could be due to the exclusion of minor biochemical compounds. Discrepancies between observed and estimated elemental compositions may, however, also partly be explained by the limited precision of the standard biochemical methods. Zamer et al. (1989), for instance, reported underestimates of protein measurements by the Lowry method (the method used by Mayzaud \& Martin [1975] for analysing proteins in C. finmarchicus). Similar sources of error have been reported for standard chitin measurement methods (Cauchie 2002), and colorimetric lipid assays (Gardner et al. 1985). Thus, the closer agreement between measured and estimated taxonomic averages could be due to the effect of compensation of the different analytical methods used when averaging the different biochemical compositions described.

The main discrepancies found were the underestimation of the $\mathrm{P}$ content of marine mysiids and freshwater cladocerans (Fig. 2). For mysiids, the measure of elemental P shown in Table 5 derives from only 1 species, Gnathophausia gigas (Ikeda 1988), while the data on biochemical compounds derives from 6 different species. Therefore, it is possible that the biochemical proportions obtained are not fully representative for those of G. gigas. For example, use of phospholipid proportions reported for this species instead of the average of all the species resulted in an increase of up 
to $65 \%$ of the explained elemental P. Similarly, as measures of nucleic acids for $G$. gigas were unavailable, data for euphausiids were used instead in this study. If G. gigas had the same concentration of nucleic acids as marine calanoid copepods and if the phospholipid concentration of the mysiid species is used, then the proportion of explained phosphorous would be $92 \%$. In contrast to mysiids, the P content of cladocerans has been subject to frequent studies (data of Table 5 comprises 25 species belonging to different families). Data on the biochemical composition of cladocerans, however, is more limited and is mainly the genus Daphnia (Appendix 1). The average $\mathrm{P}$ content of Daphnia species on which data of the nucleic acid or phospholipids composition are available was $1.16 \%$ dry weight, which is slightly lower than the cladoceran average (1.3\% dry weight). However, this would have raised the explained pool to $60.9 \%$ of the $\mathrm{P}$ pool. The remaining unaccounted $\mathrm{P}$ could be attributed to a lower estimation of any of the biochemical compounds included in this study or to an unaccounted P source. The estimated P pools were $29 \%$ for nucleic acids, $22 \%$ for phospholipids, $9 \%$ for nucleotides and $40 \%$ for the unexplained fraction. Amongst these different compounds, the proportions of ADP and AMP were the only ones estimated from the assumption that the ATP:ADM:AMP proportions of cladocerans were similar to those of marine calanoid copepods. However, if euphausiid proportions (the group with the lowest ATP:ADP ratio) had been used, the nucleic acid pool would have increased to $20 \%$, raising the explained pool to $74.6 \%$. The relative proportion of the other 2 compounds (phospholipids and nucleic acids) of the $\mathrm{P}$ pool has been investigated in a study of P partitioning in cladocerans and copepods (Vrede et al. 1999). Vrede et al. (1999) found that the relative proportions of nucleic acids in the cladocerans, Daphnia galeata and D. magna, ranged between 36 and $59 \%$, those of phospholipids ranged between 21 and $28 \%$ and the unexplained fraction ranged between 15 and $44 \%$ of the total $\mathrm{P}$ pool. Thus, their phospholipid proportion was very similar to those predicted in this study, the nucleic acid pool being slightly higher. This agrees well with what would be expected, since the RNArelated $\mathrm{P}$ has been shown to increase linearly with the increase in P content in Daphnia (Acharya et al. 2004). Also, the P content of these 2 species in the Vrede et al. (1999) study was $1.4 \%$ (i.e. $0.24 \%$ higher than the average for Daphnia found in this study). Finally, Vrede et al. (1999) also showed that $20 \%$ of their unexplained fraction was allocated in the carapace (i.e. they found $14 \%$ of the $\mathrm{P}$ after measuring approximately $70 \%$ of the carapace) and suggested that this fraction could be in the form of inorganic calcium phosphate. In a previous study covering all crustacean groups included in this study excepting euphausiids, Salonen \& Sarvala (1978) showed that mysiids and cladocerans were the only groups whose ash calcium content could not be explained by calcium carbonate and suggested that these 2 groups of crustaceans had an unusually high pool of calcium phosphate. The results of this study support that these 2 crustacean groups have an unusually high P pool that cannot be explained by the biochemical compounds accounting for the $\mathrm{P}$ pool of the other crustacean groups. Therefore, it is possible that a relevant proportion of the body P of both Daphnia and mysiids occurs as calcium phosphate.

In a previous P-fractionation study, Corner (1973) reported that $52.8 \%$ of the total $\mathrm{P}$ content of Calanus sp. was acid soluble. The acid-soluble fraction contains primarily nucleotides and phosphates (Miyata \& Hattori 1986). This study's sum of nucleotides and the unexplained fraction in C. finmarchicus was $52.8 \%$, which is almost identical with that reported by Corner (1973), while the average nucleotide plus unmeasured fraction for the average of calanoid copepods was $34.6 \%$. For the freshwater calanoid copepod, Eudiaptomus gracilis, Vrede et al. (1999) found that the relative proportions of nucleic acids, phospholipids and the unexplained fraction of the total P pool were 51-69\%, $24-27 \%$ and $7.5-22 \%$, respectively. These values are very similar to those obtained in this study for calanoid copepods (63\% of nucleic acids, $25 \%$ of phospholipids and $12 \%$ of nucleotides). Therefore, it is likely that most of the unexplained $\mathrm{P}$ fraction in calanoid copepods was in the form of phosphate. The study results also highlight the importance of the acid-soluble fraction within the $\mathrm{P}$ pool in copepods, which might be more important than previously suggested (Sterner \& Elser 2002).

Acknowledgements. I thank J. Catalan, T. Buchaca and 3 anonymous referees for very helpful comments on earlier drafts of the manuscript. D. Balayla and A. M. Poulsen assisted in linguistic and editorial corrections. I was partially supported by a Marie Curie post-doctoral grant (MEIF-CT2005-010554).

\section{LITERATURE CITED}

Acharya K, Kyle M, Elser JJ (2004) Biological stoichiometry of Daphnia growth: an ecophysiological test of the growth rate hypothesis. Limnol Oceanogr 49:656-665

Albers CS, Kattner G, Hagen W (1996) The compositions of wax esters, triacylglycerols and phospholipids in Arctic and Antarctic copepods: evidence of energetic adaptations. Mar Chem 55:347-358

Amyot M, Pinel-Alloul B, Bastien C, Méthot G, Blaise C, Van Coillie R, Thellen C (1992) Firefly assay of ATP from freshwater zooplankton: comparison of extraction methods. Environ Toxic Water 7:295-311

Andersen T, Hessen DO (1991) Carbon, nitrogen, and 
phosphorus content of freshwater zooplankton. Limnol Oceanogr 36:807-814

Balch N (1972) ATP content of Calanus finmarchicus. Limnol Oceanogr 17:906-908

Båmstedt U (1986) Chemical composition and energy content. In: Corner EDS, O'Hara SCM (eds) The biological chemistry of marine copepods. Clarendon Press, Oxford, p 1-58

Beaton MJ, Hebert PDN (1989) Miniature genomes and endopolyploidy in cladoceran crustacean. Genome 32: 1048-1053

Burkholder PK, Mandelli EF, Centeno P (1967) Some chemical properties of Munida gregaria and Euphausia superba. J Agr Food Chem 15:718-720

Cauchie H-M (2002) Chitin production by arthropods in the hydrosphere. Hydrobiologia 470:63-96

Cavaletto JF, Vanderploeg HA, Gardner WS (1989) Wax esters in two species of freshwater zooplankton. Limnol Oceanogr 34:785-789

Clarke A (1980) The biochemical composition of krill, Euphausia superba Dana, from South Georgia. J Exp Mar Biol Ecol 43:221-236

Corner EDS (1973) Phosphorus in marine zooplankton. Water Resour 7:93-110

Cowey CB, Corner EDS (1963a) Amino acids and some other nitrogenous compounds in Calanus finmarchicus. J Mar Biol Assoc UK 43:485-493

Cowey CB, Corner EDS (1963b) On the nutrition and metabolism of zooplankton II. The relationship between the marine copepod Calanus helgolandicus and particulate material in playmouth sea water, in terms of amino acid composition. J Mar Biol Assoc UK 43:495-511

Dabrowski K, Rusiecki M (1983) Content of total and free amino acids in zooplanktonic food of fish larvae. Aquaculture 30:31-42

Desvilettes C, Bourdier G, Breton JC (1997) On the occurrence of a possible bioconversion of linolenic acid into docosahexaenoic acid by the copepod Eucyclops serrulatus fed on microalgae. J Plankton Res 19:273-278

Desvilettes C, Bourdier G, Breton JC, Combrouze P (1994) Fatty acids as organic markers for the study of trophic relationships in littoral cladoceran communities of a pond. J Plankton Res 16:643-659

Dufresne F, Hebert PDN (1995) Polyploidy and clonal diversity in an arctic cladoceran. Heredity 75:45-53

Ederington MC, McManus GB, Harvey HR (1995) Trophic transfer of fatty acids, sterols, and a triptenoid alcohol between bacteria, a ciliate and the copepod Acartia tonsa. Limnol Oceanogr 40:860-867

Elser JJ, Hassett RP (1994) A stoichiometric analysis of the zooplankton-phytoplankton interaction in marine and freshwater ecosystems. Nature 370:211-213

Elser JJ, Acharya K, Kyle M, Cotner J and 8 others (2003) Growth rate-stoichiometry couplings in diverse biota. Ecol Lett 6:936-943

Elser JJ, Dobberfuhl DR, MacKay NA, Schampel JH (1996) Organism size, life history, and N:P stoichiometry. Toward a unified view of cellular and ecosystem process. Bioscience 46:674-684

Elser JJ, Fagan WF, Denno RF, Dobberfuhl DR, Folarin A and 7 others (2000a) Nutritional constraints in terrestrial and freshwater food webs. Nature 408:578-580

Elser JJ, Sterner RW, Gorokhova E, Fagan WF, Markow TA and 5 others (2000b) Biological stoichiometry from genes to ecosystems. Ecol Lett 3:540-550

Falk-Petersen S, Sargent JR, Loenne OJ, Timofeev S (1999) Functional biodiversity of lipids in Antarctic zooplankton: Calanoides acutus, Calanus propinquus, Thysanoessa macrura and Euphausia crystallorophias. Polar Biol 21: $37-47$

Farkas T (1979) Adaptation of fatty acid compositions to temperature-a study on planktonic crustaceans. Comp Biochem Physiol 64B:71-76

Farkas T, Nemecz GY, Csengeri I (1984) Differential response of lipid metabolism and membrane physical state by an actively and passively overwintering planktonic crustacean. Lipids 19:436-442

Farkas T, Storebakken T, Bhosle NB (1988) Composition and physical state of phospholipids in calanoid copepods from India and Norway. Lipids 26:619-622

Ferguson CF, Raymont JKB (1974) Biochemical studies on marine zooplankton. J Mar Biol Assoc UK 54:719-725

Gardner W, Miller WH (1981) Intracellular composition and net release rates of free amino acids in Daphnia magna. Can J Fish Aquat Sci 38:157-162

Gardner WS, Frez WA, Cichocki EA, Parrish CC (1985) Micromethod for lipids in aquatic invertebrates. Limnol Oceanogr 30:1099-1105

Goulden CE, Henry LL (1984) Lipid energy reserves and their role in Cladocera. In: Meyers DG, Strickler JR (eds) Trophic interactions within aquatic ecosystems. AAAS Selected Symposium, Vol 85:167-186

Goulden CE, Place AR (1993) Lipid accumulation and allocation in Daphniid-Cladocera. Bull Mar Sci 53:106-114

Gregory TR (2001) Coincidence, coevolution, or causation? DNA content, cell size, and the C-value enigma. Biol Rev 76:65-101

Guisande C, Bartumeus F, Ventura M, Catalan J (2003) Role of food partitioning in structuring the zooplankton community in mountain lakes. Oecologia 136:627-634

Hagen W, Kattner G, Graeve M (1995) On the lipid biochemistry of polar copepods: compositional differences in the Antarctic calanoids Euchaeta antarctica and Euchirella rostromagna. Mar Biol 123:451-457

Harris RR (1969) Free amino acid and haemolymph concentration changes in Sphaeroma rugicauda (Isopoda) during adaptation to a dilute salinity. J Exp Biol 50:319-326

Hassett RP, Cardinale B, Stabler LB, Elser JJ (1997) Ecological stoichiometry of $\mathrm{N}$ and $\mathrm{P}$ in pelagic ecosystems: comparison of lakes and oceans with emphasis on the zooplankton-phytoplankton interaction. Limnol Oceanogr 42: 648-662

Hessen DO, Lyche A (1991) Inter- and intraspecific variations in zooplankton element composition. Arch Hydrobiol 121: 343-353

Hochachka PW, Somero GN (2002) Biochemical adaptation: mechanism and process in physiological adaptation. Oxford University Press, Oxford

Ikeda T (1988) Metabolism and chemical composition of crustaceans from the Antarctic mesopelagic zone. Deep-Sea Res Pt A 35:1991-2002

Jeffries HP (1969) Seasonal composition of temperate plankton communities: free amino acids. Limnol Oceanogr 14: $41-52$

Jeffries HP, Alzara L (1970) Dominance-diversity relationships of the free amino acids in coastal zooplankton. Comp Biochem Physiol 37:215-223

Kattner G, Hagen W, Falk-Petersen S, Sargent JR, Henderson RJ (1996) Antarctic krill Thysanoessa macrura fills a major gap in marine lipogenic pathways. Mar Ecol Prog Ser 134: 295-298

Lee R, Hirota J, Barnett AM (1971a) Distribution and importance of wax esters in marine copepods and other zooplankton. Deep-Sea Res Pt A 18:1147-1165

Lee RF, Nevenzel JC, Paffenhöfer GA (1971b) Importance of 
wax esters and other lipids in the marine food chain: phytoplankton and copepods. Mar Biol 9:99-108

Main TM, Dobberfuhl DR, Elser JJ (1997) N:P stoichiometry and ontogeny of crustacean zooplankton: a test of the growth rate hypothesis. Limnol Oceanogr 42: $1474-1478$

Mauchline J (1998) The biology of calanoid copepods. Academic Press, London

Mayzaud P, Albessard E, Virtue P, Boutoute M (2000) Environmental constraints on the lipid composition and metabolism of euphausiids: the case of Euphausia superba and Meganyctiphanes norvegica. Can J Fish Aquat Sci 57: 91-103

Mayzaud P, Boutoute M, Alonzo F (2003) Lipid composition of the euphausiids Euphausia vallentini and Thysanoessa macrura during summer in the Southern Indian Ocean. Antarct Sci 15:463-475

Mayzaud P, Martin JLM (1975) Some aspects of the biochemical and mineral composition of marine plankton. J Exp Mar Biol Ecol 17:297-310

McLaren IA, Sevigny JM, Frost BW (1989) Evolutionary and ecological significance of genome sizes in the copepod genus Pseudocalanus. Can J Zool 67:565-569

McLaren IA, Woods SM, Shea JR (1966) Polyteny-a source of cryptic speciation among copepods. Science 153: 1641-1647

Miyata K, Hattori A (1986) A simple fractionation method for determination of phosphorus components in phytoplankton: application to natural populations of phytoplankton in summer surface waters of Tokyo bay. J Oceanogr Soc Jpn 42:255-265

Morris RJ (1984) The endemic faunae of Lake Baikal: their general biochemistry and detailed lipid composition. Proc R Soc Lond B 222:51-78

Reinhardt SB, Van Vleet ES (1986) Lipid composition of twenty-two species of Antarctic midwater zooplankton and fish. Mar Biol 91:149-159

Saiz E, Calbet A, Fara A, Berdalet E (1998) RNA content of copepods as a tool for determining adult growth rates in the field. Limnol Oceanogr 43:465-470

Salonen K, Sarvala J (1978) Estimation of the inorganic fraction of total carbon in aquatic invertebrates. Verh Int Verein Limnol 20:1221-1225

Santer B (1998) Life cycle strategies of free-living copepods in fresh waters. J Mar Syst 15:327-336

Sargent JR, Falk-Petersen S (1988) The lipid biochemistry of calanoid copepods. Hydrobiologia 167/168:101-114

Shin HC, Nicol S, King RA (2003) Nucleic acid content as a potential growth rate estimator of Antarctic krill, results from field-caught krill from the Indian sector of the Southern Ocean. Mar Freshw Behav Physiol 36:295-305

Sidhu GS, Montgomery WA, Holloway GL, Johnson AR, Walker DM (1970) Biochemical composition and nutritive value of krill. J Sci Food Agr 21:293-296

Skjoldal HR (1981) ATP concentration and adenylate energy

Editorial responsibility: Michael Landry (Contributing Editor), La Jolla, California, USA charge of tropical zooplankton from waters inside the Great Barrier Reef. Mar Biol 62:119-123

Skjoldal HR, Båmstedt U (1977) Ecobiochemical studies on the deep-water pelagic community of korsfjorden, Western Norway. Adenine nucleotides in zooplankton. Mar Biol 42:197-211

Smith M (1964) Deoxyribonucleic acids of Crustacea. J Mol Biol 9:17-23

Srinivasagam RT, Raymont JEG, Moodie CF, Raymont KKB (1971) Biochemical studies on marine zooplankton $X$. The amino acid composition of Euphausia superba, Meganyctiphanes norvegica and Neomysis integer. J Mar Biol Assoc UK 51:917-925

Sterner RW, Elser JJ (2002) Ecological stoichiometry. Princeton University Press, Princeton, NJ

Strayer L (1988) Biochemistry. WH Freeman, New York

Suyama M, Nakajima K, Nonaka J (1965) Studies on the protein and non-protein nitrogenous constituents of Euphausia. Bull Jpn Soc Scient Fish 31:302-306

Tang KW, Dam HG (1999) Limitation of zooplankton production: beyond stoichiometry. Oikos 84:537-541

Urabe J (1993) N-cycling and P-cycling coupled by grazers' activities: food quality and nutrient release by zooplankton. Ecology 74:2337-2350

Vanderploeg HA, Gardner WS, Parrish CC, Liebig JR, Cavaletto JF (1992) Lipids and life-cycle strategy of a hypolimnetic copepod in Lake Michigan. Limnol Oceanogr 37: 413-424

Ventura M, Catalan J (2005) Reproduction as one of the main causes of temporal variability in the elemental composition of zooplankton. Limnol Oceanogr 50:2043-2056

Vrede T, Andersen T, Hessen DO (1999) Phosphorus distribution in three crustacean zooplankton species. Limnol Oceanogr 44:225-229

Vrede T, Persson J, Aronsen G (2002) The influence of food quality (P:C ratio) on RNA:DNA ratio and somatic growth rate of Daphnia. Limnol Oceanogr 47:487-494

Wagner M, Durbin E, Buckley L (1998) RNA:DNA ratios as indicators of nutritional condition in the copepod Calanus finmarchicus. Mar Ecol Prog Ser 162:173-181

Ward P, Shreeve RS, Cripps GC (1996) Rhincalanus gigas and Calanus simillimus: lipid storage patterns of two species of copepod in the seasonally ice-free zone of the Southern Ocean. J Plankton Res 18:1439-1454

Wyngaard GA, Rasch EM (2000) Patterns of genome size in the Copepoda. Hydrobiologia 417:43-56

Wyngaard GA, Rasch EM, Manning NM, Gasser K, Domangue R (2005) The relationship between genome size, development rate, and body size in copepods. Hydrobiologia 532:123-137

Zamer WE, Shick JM, Tapley DW (1989) Protein measurement and energetic considerations: Comparisons of biochemical and stoichiometric methods using bovine serum albumin and protein isolated from sea anemones. Limnol Oceanogr 34:256-263

Submitted: March 1, 2005, Accepted: April 3, 2006 Proofs received from author(s): September 13, 2006 